\title{
Quo Vadis Bureaucracy Reform of Indonesia: Overview of Bureaucratic Reform PhaseI Vs Phase II
}

\author{
Mantrini Indri Hapsari, S.E., Ismi Dwi Astuti Nurhaeni, Prof. Dr, M.Si., and \\ Sudarmo, Drs. Ph.D. \\ Public Administration Department, Faculty of Social and Political Sciences, \\ Universitas Sebelas Maret \\ mantrini2000@student.uns.ac.id
}

\begin{abstract}
Bureaucratic reform (BR) has passed phase I (2010 - 2014), but raises some problem to be solved that are; bureaucracy that has not been completely clean and accountable, bureaucracy that has not been effective and efficient, and public services that have not had the expected quality. Almost seven years of BR has been running and entering period II (2015 - 2019), but not showing a passable change. Based on the findings of ICW in 2016, corruption figures of Civil Servants reached $47 \%$ or 515 people became suspects. During the reform period, ASN was most caught up in corruption, involving 3,417 people. In terms of service quality, the Ombudsman Indonesia received complaints during 2016, of which complained 1,200 agencies about their services. This paper intends to criticize the journey of bureaucratic reform during the phase I and the current period, rated from the dimensions of target achievement indicators and achievements.
\end{abstract}

This article was written based on literature review and secondary data analysis on the phase I of BR report, and data on the achievement of the current year reform report. The data were compared and then analyzed.

The BR in the phase I refer to national and global indicators, namely indexes of corruption perception, government effectiveness and competitiveness, and in phase II only refers to national indicators. The results found that the phase I bureaucracy reform has not been able to demonstrate good reform performance since it has not met the target of all indicators. Phase II used indicator is more internally, but not yet measured its success. BR in the phase I and phase II are more reporting and do not touch on the essence of the bureaucracy itself, bureaucratic reform is more of a "reform bureaucratization" and still relies on the approach of reporting in evaluating its success.

Keywords: reform, bureaucracy, Indonesia

\section{Introduction}

Bureaucracy reform has become a necessity in a country (including Indonesia), which goals are to improve the quality of public services, reduce inefficiency of inspectors, improve the efficiency of public organizations, and create a conducive environment for private sector investment (Chittoo, Ramphul, \& Nowbutsing, 2009). Public sector reforms help governments be more responsive to the needs and demands of citizens and can improve service delivery systems and improve governance (Haruna \& Fusein, 2003). 
Reforms can improve administration more effectively, reduce corruption, and attract investment (Neshkova \& Kostadinova, 2012). Bureaucracy reform is a major change in the paradigm and governance, including changes in the structure and repositioning of bureaucracy, changes in political and legal systems as a whole, changes in mental and cultural attitudes of bureaucrats and society, and changes in mindset and commitment of government and political parties (Prasojo \& Kurniawan, 2008).

Research on bureaucratic reform has been widely practiced in various countries, with various studies focusing, from the slow pace of reform in Cambodia (Turner, 2013), local government reform in Norway (Torsteinsen, 2011), e-government in Africa (Bruns, et.al, 2013), institutional crisis, inconsistency and legitimacy in Nigeria (Ikeanyibe, 2015), the dominance of civil-military elitism in bureaucracy in Banglasdesh (Mollah, 2014), governance reform in Kazakhstan (Haruna \& Fusein, 2003), and performance improvement and public services in Kenya (Hope, 2012). Nevertheless, bureaucracy reform research that sees the achievement of the target indicators has never been done.

The collapse of the New Order regime brought significant changes in the bureaucracy in Indonesia. Year 2010 marked as a milestone for the government to build good governance, in which all ministries / institutional reforms must be carried out. The Vision of Indonesian Bureaucracy Reform (BR) is to become a world-class government by 2025. Its missions are (1) to improve the legislation in order to embody good governance. (2) organizing and managing the organization, management, servant resource management, supervision, accountability, quality of public services, mindset, and culture-set. (3) develop an effective control mechanism. (4) managing administrative disputes effectively and efficiently (GDRB, 2010).

For that, it is needed a Grand Design Bureaucratic Reform (GDRB) which takes time 2010-2025. GDRB is a reference for ministries/agencies in conducting bureaucratic reforms in its scope of work. Implementation of GDRB is set forth in the Road Map as the operationalization of GDRB which is a detailed plan of BR from stage to stage for 5 years with clear goal per year. GDBR is divided into 3 (three) periods of 2010-2014, 2015-2019 and 2020 -2024. The first period target (2010-2014) focuses on strengthening government bureaucracy in order to realize clean and coruption collution nepotism (CCN)-free government, improve public service quality to the community, and improve the capacity and accountability of bureaucratic performance. The second period target (2015-2019) implements the first five-year results and continues unreached efforts on the strategic components of the government bureaucracy in the first five years.

BR is entering the period II, where the results have not shown a good change, seen from the number of corruption committed by the authorities. Findings of Indonesia Corruption Watch ICW) in 2016, corruption figures of state civil servants (ASN) reached $47 \%$ or 515 people became suspects. During the reformation, ICW found ASN as the most corrupt actor, involving 3,417 people during 2010 - 2016 (ICW, 2017). The quality of public service is still far from being expected. The Ombudsman received 10,158 complaints during 2016, and 1,200 of which were copies of reports from the agency's which service were complained (Ombudsman, 2017). This paper intends to describe how the journey of bureaucratic reform during the phase I (2010-2014) and phase II (2015-2019) seen from the indicators of achievement of targets. 


\section{Method}

This article is written based on literature review and secondary data analysis. Caston (2005) stated that the secondary data analysis includes two principal processes, collecting data and analyzing them. Secondary data were collected based on the report of bureaucracy reform stage I, and data on the achievement of the reform of the current year based on the ministry/agency report. The data were compared then analyzed. The analysis includes interpretations, conclusions or additional knowledge in other forms. All this is shown through the first comprehensive research results. The search for data is related to the results achieved in bureaucratic reforms based on data from search through internet search engines in the form of reports or other information. The data are then collected and grouped according to need and then analyzed.

\section{Result}

Implementation of bureaucracy reform (BR) in 2010-2014 refers to the three targets is the realization of a clean and $\mathrm{CCN}$-free government, the realization of improved public services quality, and increased capacity and accountability of bureaucratic performance. The achievements of phase I can be seen in table 1 .

Table 1. Achievements of the Reform Phase I (2010-2014)

\begin{tabular}{|l|l|l|l|}
\hline Targets and Indicators & \multirow{2}{*}{ Base line } & \multicolumn{2}{|c|}{$\mathbf{2 0 1 0}$-2014 } \\
\cline { 3 - 4 } & & Target & Achieved \\
\hline Target 1. Clean and CNN-free government & & & \\
Corruption Perceptions Index (CPI) & 2.8 & 50 & 34 \\
$\begin{array}{l}\text { Supreme Audit Institution (BPK) Opinion } \\
\text { (RWE) \% }\end{array}$ & 42,17 & 100 & 76 \\
$\quad$ Central & 2,73 & 60 & 35 \\
$\quad$ Regions & & & \\
\hline $\begin{array}{l}\text { Target 2. Improved public services quality } \\
\text { to the society }\end{array}$ & & & \\
$\quad$ Integrity of Public Service & 6,64 & 8.0 & 7,22 \\
$\quad \begin{array}{l}\text { Central } \\
\text { Regions }\end{array}$ & 6,46 & 8,0 & $n .9$ \\
Ease of Business Rank & 122 & 75 & 114 \\
\hline Target 3.Increased capacity and & & & \\
accountability of BR & & & \\
Government Effectiveness Index & $-0,29$ & 0,5 & -0.01 \\
Accountable Government Agencies (\%) & & & \\
$\quad \begin{array}{l}\text { Province } \\
\text { Central }\end{array}$ & 47,4 & 100 & 98,76 \\
City & 3,8 & 80 & 87,88 \\
\hline
\end{tabular}

Source: Roadmap BR 2015-2019 
The results of the performance of the reforms in the phase I appear not to give the expected results. The CPI indicator, Ease of Business Rank and Government Effectiveness Index (GEI) are quite low from the target. BPK opinion indicator, the integrity of public services and the number of accountable government agencies are quite close to the target. Based on the Road Map, the implementation of BR in phase I raised issues to be solved, which are; bureaucracy has not been completely clean and accountable, bureaucracy has not been effective and efficient, and public services have not had the expected quality.

\section{Bureaucratic Reform (2015-2019)}

The continuous implementation of BR has an important role in realizing good governance. The results that have been obtained in the phase I become the basis for BR phase II. The targets are a clean and healthy bureaucracy, an effective and efficient bureaucracy, and a bureaucracy that has a certain quality public services. The measurement of success and target of BR phase II shown in table 2.

Table 2. Achievement of the Reform Phase II (2015-2019)

\begin{tabular}{|c|c|c|c|c|}
\hline \multirow[b]{2}{*}{ Target and Indicator } & \multicolumn{4}{|c|}{$2015-2019$} \\
\hline & $\begin{array}{c}\text { Baseline } \\
2009\end{array}$ & 2015 & 2016 & Target \\
\hline \multicolumn{5}{|l|}{ Target 1. Clean CNN-free government } \\
\hline \multicolumn{5}{|l|}{ BPK Opinion (RWE) \% } \\
\hline Ministry/Institution & 74 & 65 & 84 & 95 \\
\hline Province & 53 & 53 & 91 & 85 \\
\hline District & 18 & 17 & 66 & 60 \\
\hline City & 33 & 17 & 77 & 65 \\
\hline GISS Capability Level & 1 & NA & NA & 3 \\
\hline GICS Maturity Level Implementation & 1 & NA & NA & 3 \\
\hline Accountable Government Agencies (Score B on & & & & \\
\hline GAPA) & 39.3 & NA & NA & 85 \\
\hline Ministry/Institution & 27.3 & NA & NA & 75 \\
\hline Province & 30 & NA & NA & 50 \\
\hline District/City & & & & \\
\hline Use of e-Procurement on Procurement Spending & 39.3 & NA & NA & 80 \\
\hline \multicolumn{5}{|l|}{ Target 2. Effective and efficient bureaucracy } \\
\hline \multicolumn{5}{|l|}{ Central Mean Bureaucracy Reform Index (1-100) } \\
\hline Ministry/Institution & 47 & 66,13 & 69,58 & 75 \\
\hline Province & NA & 41,62 & 56,69 & 60 \\
\hline District/City & NA & 42,97 & 56,23 & 45 \\
\hline ASN Professionalism Index (1-100) & 76 & TA & TA & 86 \\
\hline \multicolumn{5}{|l|}{ National e-Government Index (0-4) } \\
\hline Ministry/Institution & 2,66 & 2,7 & NA & 3,4 \\
\hline Province & 2,2 & NA & NA & \\
\hline District/City & 2,2 & NA & NA & \\
\hline
\end{tabular}




\begin{tabular}{|l|c|c|c|l|}
\hline & \multicolumn{3}{|c|}{$\mathbf{2 0 1 5}-\mathbf{2 0 1 9}$} \\
\cline { 2 - 5 } Target and Indicator & $\begin{array}{c}\text { Baseline } \\
\mathbf{2 0 0 9}\end{array}$ & $\mathbf{2 0 1 5}$ & $\mathbf{2 0 1 6}$ & Target \\
\hline public service & & & & \\
Government Integrity Index (0-10) & & & & \\
Integrity of Public Services (Central) & 7,22 & NA & NA & 9 \\
Integrity of Public Services (Regions) & 6,82 & NA & NA & 8,5 \\
Public Satisfaction Survey (PSC) \% & 80 & NA & NA & 95 \\
Percentage of Compliance Implementation of Public & & & & \\
Service Law (Green Zone)\% & & & & \\
$\quad$ Ministry/Institution & $54 ; 15$ & $44 ; 66$ & $23 ; 2$ & 100 \\
Province & 5 & $39 ; 5$ & 9 & 80 \\
District/City & & & $29 ; 6$ & \\
\hline
\end{tabular}

Source: Roadmap BR 2015-2019 and library

In target 1, Reasonable Without Exception Opinion (RWE) is provided if the financial statements are deemed to provide information free of material misstatement. During 2015 and 2016 RWE opinion by BPK for ministries/institutions has increased and has exceeded the target. Based on the assessment of capability level GISS for ministries, institutions and local governments in 2015 and 2016 there has been no report. Another incicator, the maturity level of the Government's Internal Control System (GICS) is a process that is more likely to lead to better output and outcomes. This shows the level of maturity of the implementation of the GICS is structured and sustainable. This indicator can provide improved performance, transparency and accountability of state/local financial management in the government environment. In 2015 and 2016 the report have not yet been found. The indicaor of GAPA is an integration of the planning system, budgeting system and performance reporting system, in line with the implementation of the financial accountability system. In this case, each organization is required to record and report any use of state finances and their compliance with applicable provisions. The GAPA value indicates the level of accountability or accountability for the outcome of the use of the budget in the context of the realization of results-oriented governance. However, in detail the achievements of GAPA that are in accordance with the BR indicators have not yet been found.

Target 2, the e-procurement system through the Electronic Procurement Service (EPS) is a work unit established in all institutions to organize electronic procurement service system. The procurement of goods and services electronically will increase transparency and accountability, promote market access, fair business competition, and improve the efficiency of the procurement process. This will indirectly support the monitoring and auditing process and meet the need for real-time access to information in order to create clean and good government in the procurement of government goods and services. For more detailed data, we have not yet been found. The implementation of BR, especially in district/city is in line with expectations and there is an increase of index of BR in 2015 and 2016. For ASN, The State Personnel Board launched the Civil State Professional Apparatus Certification Program. 
This is used as a reference to cover the gap of civil servant competence. Components of professional index calculation include objective assessment of potential employee based on education, experience, technical training and leadership training, and employee performance goals. In addition, there are differences in salaries and benefits, including performance allowances, internally on the complexity of work and equal risk and level of individual violations within the institution. The new launch was conducted in 2017, so it so the results have not come out yet. The Ranking of E-government activity is conducted to view the map of the utilization of information and communication technology (ICT) at government agencies throughout Indonesia in the existing data that can not be found the index of eGovernment in more comprehensively and comprehensively. Firdaus (2017), the development of e-government in Indonesia decline compared to some countries in Southeast Asia. The e-government survey conducted by the United Nations (UN) through data released by public administration.un.org, Indonesia is in position 116 of 193 countries.

Target 3, National Integrity Index is judged by the integrity of public services at central and regional levels KPK in 2014 was conducted against 40 service units in 20 ministries/agencies in the greater Jakarta area expanding the 2016 Public Sector Integrity Survey scale to 64 agencies and ministries. We have not found data related to it. The quality of public services is the main indicator in good governance, from the central government to the local government. Therefore, in order to improve the quality of public services in a sustainable manner, the government sets out a policy to conduct a public satisfaction survey for public service providers under the Regulation of the Minister of PAN-RB. We did not find the results of the survey comprehensively. Denhardt \& Denhardt (2000) introduced the concept of the NPS in the government bureaucracy: 1) serve, rather steer; 2) public interest is purpose, not product; 3) strategic thinking but democratic action; 4) serving citizens, not fulfilling customers' wishes; 5) cccountability is not simple 6) respect people not just about productivity, and 7) respect citizenship and service beyond entrepreneurship. The public interest will be well fulfilled if bureaucrats committed to making a meaningful contribution to society rather than highlighting the profit-making entrepreneurship side.

Percentage Compliance Implementation Act (Act) Public Service of Green Zone conducted by the Ombudsman. In 2015 to 2016 are reported levels of compliance with the implementation of the law on institutions in the high category is still slightly below. It can be analyzed the compliance in the implementation of public services is not as expected, whereas this Act has emerged since 2009.

\section{Comparison of Results of BR on Phase I and II}

The sizes of the reform achievement indicators in all phases are different, but the outline of the targets of each period has similarities. Comparison of target and achievement indicators can be seen as follows: 
Table 3. Indicators of Reform Achievement Period I and Period II

\begin{tabular}{|c|c|c|}
\hline $\begin{array}{c}\text { Target and Indicator } \\
\text { Phase I }\end{array}$ & $\begin{array}{c}\text { Target and Indicator } \\
\text { Phase II }\end{array}$ & Analysis \\
\hline $\begin{array}{l}\text { Target } 1 . \text { The bureaucracy is } \\
\text { clean and free-CCN }\end{array}$ & $\begin{array}{l}\text { Target } 1 . \text { The bureaucracy } \\
\text { is clean and free-CCN }\end{array}$ & \multirow{7}{*}{$\begin{array}{l}\text { There is a } \\
\text { difference in the } \\
\text { indicators of target } \\
\text { achievement by } \\
\text { removing the } \\
\text { global IPK index } \\
\text { and adding national } \\
\text { indicators }\end{array}$} \\
\hline $\begin{array}{l}\text { Corruption Perceptions Index } \\
\text { (CPI) }\end{array}$ & - & \\
\hline \multirow[t]{5}{*}{ BPK opinion (RWE) } & BPK opinion (RWE) & \\
\hline & GISS Capability Level & \\
\hline & $\begin{array}{l}\text { Maturity Level of GICS } \\
\text { Implementation }\end{array}$ & \\
\hline & Score B on GAPA & \\
\hline & Use of e-Procurement & \\
\hline $\begin{array}{l}\text { Target } 2 . \text { Improving the } \\
\text { quality of Public Services to } \\
\text { the public }\end{array}$ & $\begin{array}{l}\text { Target } 2 . \text { Bureaucracy that } \\
\text { has a quality public service }\end{array}$ & \multirow{5}{*}{$\begin{array}{c}\text { There is a } \\
\text { difference in target } \\
\text { achievement } \\
\text { indicators by } \\
\text { eliminating } \\
\text { indicator ease of } \\
\text { bussiness rank and } \\
\text { adding national } \\
\text { indicators }\end{array}$} \\
\hline Ease of Business Rank (EBR) & - & \\
\hline \multirow[t]{3}{*}{ Integrity of Public Service } & Government Integrity Index & \\
\hline & Public Satisfaction Survey & \\
\hline & $\begin{array}{l}\text { Compliance Implementation } \\
\text { of the Law on Public Service }\end{array}$ & \\
\hline $\begin{array}{l}\text { Target } 3 \text {. Improved capacity } \\
\text { and accountability of } \\
\text { bureaucratic performance }\end{array}$ & $\begin{array}{l}\text { Target 2. Effective and } \\
\text { efficient bureaucracy }\end{array}$ & \multirow{6}{*}{$\begin{array}{l}\text { There is a } \\
\text { difference in the } \\
\text { indicators of } \\
\text { achieving targets } \\
\text { by eliminating } \\
\text { government } \\
\text { effectiveness and } \\
\text { adding national } \\
\text { indicators }\end{array}$} \\
\hline $\begin{array}{l}\text { - Government Effectiveness } \\
\text { Index }\end{array}$ & - & \\
\hline $\begin{array}{l}\text { - Accountable Government } \\
\text { Agencies }\end{array}$ & - & \\
\hline & BR Index Reforms & \\
\hline & ASN Professionality Index & \\
\hline & Index e - National Goverment & \\
\hline
\end{tabular}

\section{Source: Roadmap RB 2009-2014 and 2015-2019}

In phase I, the main indicators used refers to the global assessment indexes of corruption perception, government effectiveness and competitiveness. Using the same indicators, we can see the success rate of second stage bureaucracy reform, ie IPK, EBR and GEI in 2014, 2015 and 2016. 
Table 4. Comparison of Global Indicator Achievements

\begin{tabular}{|l|c|c|c|c|}
\hline \multirow{2}{*}{ Global Indicator } & \multicolumn{3}{c|}{ Achievement } & Analysis \\
\cline { 2 - 5 } & $\mathbf{2 0 1 4}$ & $\mathbf{2 0 1 5}$ & $\mathbf{2 0 1 6}$ & \\
\hline $\begin{array}{l}\text { Corruption Perceptions Index (1- } \\
\text { 100) }\end{array}$ & 34 & 36 & 37 & $\begin{array}{c}\text { Increasing but } \\
\text { showing little } \\
\text { improvement } \\
\text { prevention of } \\
\text { corruption has } \\
\text { not run } \\
\text { maximally }\end{array}$ \\
\hline Ease of Business Rank (0-100) & 114 & 120 & 109 & Fluctuate \\
\hline $\begin{array}{l}\text { Government Effectiveness Index (- } \\
\text { 2,5-2,5) }\end{array}$ & 2,5 & -0.22 & n.a & Still low \\
\hline
\end{tabular}

Source: Roadmap RB 2015-2019 and library

\section{Discussion}

Measures of BR performance indicators for two periods are different. Phase I refers to national and global indicators, in the phase II that ignore the outside element, the indicators more to the internal assessment. In the indicators used in phase I can already be seen the results and existing assessment has not been able to show the performance of good reform, because of all the indicators that have not met the target.

In the second period, President Joko Widodo carried Nawacita, the indicators used are more internal. Under the leading sector of the Minister of PAN-RB Yuddy Chrisnandy, the assessment indicator used, according to the authors, leads more to the internal assessment of government such as BPK, Ombudsman, KPK, Ministry of PAN-RB, Ministry of Communications and Informatics, and BPKP. In the previous period, assessment indicators also involved World Bank instruments, Transparency International, and the World Economy Forum.

This thing raises the accountability questions of each assessment, and whether the indicator measures are able to demonstrate the performance of the RB. Indicators that have been set for five years must be measured in each year so that the achievement can be monitored, but the authors have not found data related to the indicator in question. Indicators used are also quite a lot that takes time in the measurement so that it can not assess the performance of this RB simultaneously in the early year of phase II.

Assessment of RWE opinion indicator on financial report, level of GISS capability, maturity level of GICS implementation, performance GAPA score assessed from Accountable Government Institution, and use of e-procurement to procurement expenditure is an indicator of accountability of financial report. This indicator is also very administrative and does not rule out the occurrence of fraud. For example, the use of e-procurement conducted by the satker agency only uploads general procurement plans. Assessments based on self-assessment, such as GICS tend to be vulnerable to data manipulation. Due to the implementation of GICS at the micro level, the smallest work unit does not have the government internal supervisory apparatus which internally assesses all activities in the 
institution. At the micro level it ends up just trying to meet monthly report targets requested by its top agencies. It is paradox that government reform aims to reform the bureaucracy more formalistic (Torsteinsen, 2011).

National Bureaucracy Reform Indexes and ASN professional indices are conducted by the Ministry of PAN-RB. The ASN Professionalism Index should be implemented and become one of the main supporters of a good bureaucracy, clean, professional and integrity, in 2017 new phase of launch, but has not seen the results. The objective of the professionalism index is not fully understood, the Employee Performance Objectives (SKP) that have been created each year can adequately represent the performance of ASN or SKP that has been done only fulfill the obligation of employee administration and the acquisition of performance allowance. Hanif et al (2016) reveals that the Pakistani Civil Service performance management system has the power of accuracy, completeness, discipline of tools for promotion and accountability but lacks quantification and standardization that impedes the effective functioning of the system. Akrivos, Reklitis, \& Prifti (2013) conduct research on public administration reforms with the aim of enhancing the effectiveness of strategic change using a questionnaire instrument with a scaledert to dig the respondents, ie government employees. The results show that the most important element in the implementation of change is the human resources due to the organization's "blood". So to achieve success in organizational change it is advisable to pay attention to aspects of employees including motivation, job satisfaction, performance standards and service quality that will ultimately affect organizational performance, customer satisfaction and loyalty.

The national integrity index is assessed by the KPK, but whether the assessment is also sufficient to measure the interaction of public services. Meanwhile, the community satisfaction survey is conducted by each ministry institution by referring to the rules of the Ministry of PAN-RB. Percentage of compliance indicators of the implementation of the Public Service Act is implemented by the Ombudsman.

$\mathrm{CPI}$ is one of the indicators in RB phase I, but this indicator is omitted. Corruption is one of the bureaucratic pathologies in Indonesia, the CPI of 2013, 2014 and 2015 respectively 34,36 and 37 (of the net index value of corruption 100). In every year has increased but slow, whereas bureaucratic reform has been going on for quite a while. Bureaucratic reform should be a panacea for corruption. In line with findings (Neshkova \& Kostadinova, 2012), indicates that once reforms are adopted, administration becomes more effective at reducing corruption and attracting investment.

The GEI includes the perception of the quality of public services, civil servants and their degree of independence from political pressure, policy formulation and implementation, and the credibility of the government's commitment to the policy. The GEI is between low 2.5 to 2.5. The World Bank has data for Indonesia, the GEI in 2015 is still very low with index value - 0.22. Research in Kazakhstan on public sector reform and reform efforts has helped the government to be more responsive to the needs and demands of citizens The results is that substantial progress has been made in improving the service delivery system and improving good governance (Haruna \& Fusein, 2003). 


\section{Conclusion}

Both periods I and II, the GDBR, whose implementation is guarded by the Ministry of PAN$\mathrm{RB}$, need a thorough analysis in determining the policies related to BR. Because BR is more reporting and does not touch on the essence of the bureaucracy itself, so there will be concern that BR becomes more of a "reform bureaucratization" and still relies on a reporting approach in evaluating its success.

These different sizes and indicators of success are the long winding roads that must be traversed toward real reform. The change of leader or minister should not change the direction of reform, but it can facilitate the real bureaucracy of corruption-free bureaucracy and be able to answer every public problem.

ASN is the subject as well as object in BR, therefore it should be able to show better performance than ever before. An evaluation of the implementation of BR is needed to determine the effect on the performance of the government bureaucracy.

This study has limitations because the required data related to the report on the achievement of reforms is inadequate. For that we need to search the data of reform reports by digging into the source data directly.

\section{References}

Ade Irma Junida. (2015, 28 October). Peringkat Kemudahan Berusaha Indonesia. Antara. Retrieved from https://www.antaranews.com.

Agust, Supriyadi. (2016, 29 September). World Economic Forum Pangkas 4 level Daya Saing Indonesia. CNN Indonesia. Retrieved from http://www.cnnindonesia.com/ekonomi/

Akrivos C, Reklitis P, \& Prifti F. (2013). Greek Public Administration Reform. How to Improve the Effectiveness of Strategic Changes. Procedia - Sosial and avioral Sciences 73 (710-717).

Ayesha Hanif, Nasira Jabeen and Zafar Iqbal Jadoon. (2016). Performance Management in Public Sector: A Case of Civil Service in Pakistan. A Research Journal of South Asian Studies. Vol. 31, No. 1, January - June 2016, pp.99 - 116

Denhardt B, Denhardt JV. (2000). The New Public Service: Serving Rather Than Steering. Public Administration Review Vol. 60, No. 6. Arizona State University

Firdaus Masyur. (2017). Penelitian e-Goverment di Indonesia: Studi Literatur Sistematis dari Persfektif Dimensi Pemeringkatan e-Goverment Indonesia (PeGI). Retrieved from www.researchgate.net.

Harald Torsteinsen. (2011). Why Does Post-Bureaucracy Lead to More Formalisation? http://www.tandfonline.com/loi/flgs20. Published online: 16 Nov 2011.

Haruna and Peter Fusein. (2003). Reforming Ghana's public service: Issues and experiences in comparative perspective. Public Administration Review; Washington 63.3 (May/Jun 2003): 343-354.

Heldania Ultri Lubis. (2016, 08 February). 10 Ribuan Aduan Warga ke Ombudsman di 2016. Terbanyak Soal Pemda. Detik. Retrieved from http://news.detik.com.

Hemant B. Chittoo, Needesh Ramphul, \& Bhissum Nowbutsing. (2009). Globalization and public sector reforms in a developing country. Culture Mandala: The Bulletin of the Centre for East-West Cultural and Economic Studies The Bulletin of the Centre for 
East-West Cultural and Economic Studies. Tahun 2009. Volume 8 Issue 2 Article 3. Indonesia Corruption Watch. (2016). Kajian Tren Penanganan Kasus Korupsi Tahun Gagalnya Reformasi Birokrasi dan Fenomena Berkembangnya Local Elite Capture.

Kempe Ronald Hope, Sr. (2012). Managing the Public Sector in Kenya: Reform and Transformation for Improved Performance Development. Journal of Public Administration and Governance. ISSN 2161-7104 .2012, Vol. 2, No. 4

Kurniawan, RC. (2013). Reformasi Pelayanan Birokrasi. Adminitratio Jurnal Ilmiah Administrasi Publik dan Pembangunan Vo.4. No.2 Juli-December 2013. ISSN: 20870825.

Mark Turner. (2013). Why is it so difficult to reform some Asian Bereaucraties? Buliding theory. From Cambodian Evidence Public Administration and Development. Public Admin. Dev. 33, 275-285 (2013). Published online in Wiley Online.

Mc Caston, M. Katherine. (2005). Tips for Collecting, Reviewing, and Analyzing Secondary Data. www.ands.org.au. Retrieved Desember 2017

Milena I. Neshkova dan Tatiana Kostadinova. (2012). The Effectiveness of Administrative Reform in New Democracies. Public Administration Review. Vol. 72, Iss. 3, pp. 324333. () 2012 by the American Society for Public Administration. DOI: 10.111/j.15406210.2012.02483.x

Okey Marcellus Ikeanyibe. (2015). New Public Management and Administrative Reforms in Nigeria. International Journal of Public Administration. 2015. DOI: 10.1080/01900692.2015.1023446

Ombudsman Republik Indonesia (2015). Ringkasan Eksekutif. Hasil Penilaian Terhadap Standar Pelayanan da Kompetensi Peyelenggaranan Pelayanan Sesuai UU No.25 Tahun 2009 tentang Pelayanan Publik.

Ombudsman Republik Indonesia (2016). Ringkasan Eksekutif. Hasil Penilaian Terhadap Standar Pelayanan da Kompetensi Peyelenggaranan Pelayanan Sesuai UU No.25 Tahun 2009 tentang Pelayanan Publik.

Peraturan Menteri Pendayagunaan Aparatur Negara dan Reformasi Birokrasi (2010). Road Map Reformasi Birokrasi 2010-2014. Indonesia

Peraturan Menteri Pendayagunaan Aparatur Negara dan Reformasi Birokrasi (2011). Kriteria dan Ukuran Keberhasilan Reformasi Birokrasi. Indonesia

Peraturan Menteri Pendayagunaan dan Aparatur Negara. (2015). Road Map Reformasi Birokrasi 2015 - 2019. Indonesia

Prasojo E, Kurnawan T. (2008). Reformasi Birokrasi dan Good Governance: Kasus Best Practices dari Sejumlah Daerah di Indonesia. Makalah the 5th international Symposium of Antropologi Indonesia.

Wana Alamsyah. (2017, 4 July). Kegagalan Reformasi. Kompas. Retrieved from http://nasional.kompas.com/read/ 